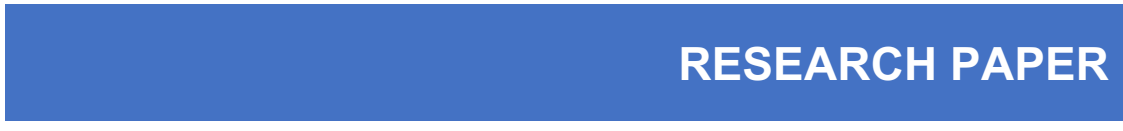

Journal homepage: https://journals.ukim.mk/index.php/ebd

\title{
Efficiency Analysis of Macedonian and Croatian Banking Sectors with DEA
}

\section{Violeta Cvetkoska, PhD \\ Ss. Cyril and Methodius University in Skopje, Faculty of Economics-Skopje, Blvd. Goce Delchev 9V, 1000 Skopje, Republic of North Macedonia vcvetkoska@eccf.ukim.edu.mk}

\author{
Katerina Fotova Čiković, PhD \\ University North, Koprivnica \\ Trg dr. Ž. Dolinara 1, 48000 Koprivnica, Republic of Croatia \\ kcikovic@unin.hr
}

\begin{abstract}
The aim of this paper is to measure the relative efficiency of commercial banks in two developing countries, the Republic of North Macedonia and the Republic of Croatia under the operating (incomebased) approach by using the leading non-parametric methodology data envelopment analysis (DEA). We follow Banker et al. (2010) in the selection of the approach, variables (two inputs: interest expense and other operating expense, and two outputs: interest revenue and other operating revenue) and the model (output-oriented BCC DEA model) as in their first stage. The observed period is five years (2015-2019) and we use a balanced panel data for both samples (total of 65 Macedonian and 100 Croatian bank-year observations). Outliers are identified and excluded by using the Banker and Gifford (1988) super-efficiency procedure, and the BCC output-oriented model is rerun for both samples (total 55 Macedonian and 95 Croatian bank-year observations). We provide relative efficiency scores for each bank in both sectors, as well as an average score for the banking sectors. In addition, we analyse few banks for both sectors that have decreased or increased the efficiency, or show variable results over time. Besides, we explain how inefficient banks can improve the efficiency in future by setting targets for improvement. Our study provides valuable information for banking management and regulatory bodies.
\end{abstract}

Keywords: banking sector, relative efficiency, DEA, BCC, developing countries

JEL classification: C67, G21

License: Authors of papers retain copyright and release the work under a Creative Commons Attribution-NonCommercial-ShareAlike 4.0 International License (c) (i)(2) (CC BY-NC-SA 4.0). 


\section{Introduction}

The financial system in developing countries is bank-based and therefore the banks' performance is of crucial importance for the stability of the financial system. Since efficiency is one of the key indicators of performance, in this paper we measure the relative efficiency of commercial banks in two developing countries, the Republic of North Macedonia and the Republic of Croatia under the operating (income-based) approach by using the non-parametric methodology data envelopment analysis (DEA).

The total share of banks in the total assets of the financial system in North Macedonia in 2019 was $81.4 \%$. In the Republic of Croatia, on the other hand, banks have a share of almost $70 \%$ of the total assets of the financial sector in 2018. The financial system of the Republic of North Macedonia has a quite simple structure, and the interdependence and interconnectedness of its segments are minimal. The Croatian financial system is characterized as other transition countries (as well as North Macedonia): the banks are the vital financial institutions, the dominant source of financing are loans, the financial markets are still underdeveloped and there is lack of diversity of tradable financial instruments on the financial market (Gulin et al., 2012).

For every profit (as well as a non-profit) organization of key importance is to measure and analyze its performance. Also, by comparing the performance against its competitors that operate in the same industry it could gain information on how it performs, i.e., to see its position and evaluate if it performs better than the competitors or shows lower performance. If the organization is identified as one of the top performers it needs to take adequate actions to continuously adapt to changes to remain in that position in the future. However, if it shows a lower performance of key importance is to learn what the top performers are doing to achieve better results and based on that to set targets for improvements. By using parametric methodologies (regression), we could obtain information on how each organization that is part of the analysis performs regarding the average performance. The parametric methodologies focus on average tendency and deviations from it. Based on that, a reference set for organizations with lower performance and targets for their improvement could not be identified. Furthermore, their application requires an assumption for the production function and they can consider only one output.

On the other side, the most popular non-parametric methodology DEA originally developed by Charnes et al. (1978) and Banker et al. (1984) measures the efficiency of decision-making units (DMUs), relative to those included in the analysis that are most efficient. The evaluation is based on the inputs they use and the outputs they produce. The relative efficient DMUs form the efficient frontier that presents an envelope for DMUs that are relative inefficient. The possibility to include more than one output and to not set assumption for the production function are one of the advantages of using DEA instead of parametric methodologies.

The founder of the efficiency measures (technical, allocative, and overall) and additionally the nonparametric methods for estimating efficiency is Farell. In his seminal paper, Farrell (1957) has graphically presented the three efficiency measures in a single output case. Charnes et al. (1978) following Farell (1957) developed the primary DEA model, the CCR model and have presented graphically DMUs and isoquant. This model assesses the total technical efficiency and the efficient frontier created to support this model is in the form of a convex cone. To assess the pure technical efficiency, Banker et al. (1984) developed the BCC model. The efficient frontier visualized by this model has a form of a convex hull.

In addition, DEA provides information for the reference set (benchmarks) for each relative inefficient unit as well as target values for inputs and outputs that will help the DMU to perform better and to achieve the frontier in the future. Over the years, DEA models have expanded and new ones have been developed to fit the research context. From the original DEA paper published in 1978 until the end of 2016 there are 10,300 published journal articles (Emrouznejad and Yang, 2018). In addition, based on published DEA articles in 2015 and 2016, they have identified that banking is one of the most applied area of DEA. 
In this paper we apply DEA to measure the relative efficiency of banks in North Macedonia and Croatia by using balanced panel data for both samples for the period of five years (2015-2019). We have made a search in the Scopus database in title-abstract-keywords with the fields: DEA and commercial banks and North Macedonia and Croatia, but no results were found, so our study will enrich the literature with this comparative analysis. In addition, we provide review for DEA papers in banking in North Macedonia and Croatia separately.

In the selection of inputs and outputs under the income-based approach, we follow Banker et al. (2010) as well in the selection of the output-oriented BCC DEA model which is used in their first-stage. Because unusual BCC-DEA results are identified in both sectors, we use the Banker and Gifford (1988) super-efficiency procedure to identify outliers and to remove them from analysis in order the results to reflect the real situation. After removing the outliers in both banking sectors, we apply again the BCC output-oriented model.

According to the obtained results, both sectors, on average show high relative efficiency for the whole observed period, i.e., $91.08 \%$ and $90.94 \%$ for the Macedonian and Croatian banking sector, respectively. In both countries, most of the relative efficient banks for the whole observed period belong to the group of large banks. On average, the minimal relative efficiency for the Macedonian banking sector is achieved in the last observed year, 2019 (56.42\%), while in Croatia in the first observed year, 2015 (62.30\%).

This paper is organized as follows. Section 2 presents the characteristics of Macedonian and Croatian banking sectors. Section 3 gives a literature review. Section 4 describes the methodology and data. Section 5 presents the obtained results and gives a comparison of the efficiency scores of both sectors, while Section 6 concludes the paper.

\section{The Banking System in North Macedonia and Croatia}

\section{The banking system in North Macedonia}

In the Republic of North Macedonia, banks have a dominant role in the financial system and a vital role in maintaining the stability of the financial system. At the time of the monetary independence, the Macedonian banking system was relatively underdeveloped and poor. Even though there were only 6 banks in 1992, the more liberal approach to the establishing new banks has accomplished the number of new banks to rise to 20 in 1993 (Cvetkoska and Fotova Čiković, 2020). The consolidation of the banking sector had begun in 2001 subsequently to the increased competition in the banking market, which resulted from the foreign capital inflow, which in 2019 amounts for $75.4 \%$ of the total assets in the banking sector.

The banking system participates with $91.6 \%$ in the total profit of the financial sector. In addition, it has the highest share in assets in the financial system and continuously contributes the most to its absolute growth in the observed period. The structural participation of banks in the total assets of the financial system in 2019 has been staggering 81.4\% (Financial stability report for the Republic of North Macedonia in 2019, 2020). Despite the continuous growth of the financial system, comparative analysis at the level of financial intermediation with other countries from Central and South-Eastern Europe points to a modest domestic size of the Macedonian financial sector. The largest and most important segments of the financial system are in predominant ownership of foreign shareholders.

As a key segment of the financial system, the Macedonian banking system has remained stable in the analysed period, maintaining its high capitalization and a stable solvency position, with a capital adequacy ratio in 2019 of 16.3\% (Financial Stability Report for the Republic of North Macedonia in 2018, 2019).

\section{The banking system in Croatia}


At the beginning of 1990-ies, the Croatian economy (as well as all the other Ex-Yugoslavian economies) was faced with a transition process and this transformation had made a big impact on the economy and on its banking sector (Tomičić et al., 2012). Due to the acceleration of the banking system consolidation process in 2018, the number of credit institutions declined, as a result of mergers and exits from the system (bankruptcy and winding-up proceedings). The banking sector in Croatia in 2019 consists of 20 commercial banks.

What is vital to mention in this observed period is the collapse of Agrokor Group in 2017 and its effect on the banking system. It has largely affected banks' profitability. Even though the banks' profits had been encumbered by expenses related to credit risk of the Agrokor Group in 2017, they managed to recover. In 2018 the banks' profits increased by nearly $50 \%$ as a result of the sharp decline in impairment and provision expenses.

The indicators of banking system concentration show an increase of the otherwise high concentration in the observed period. The share of assets of the first five banks (Zagrebačka Banka, Privredna Banka Zagreb, Erste \& Steiermaerkische Bank, Raiffeisenbank Austrija and Societe Generale-Splitska Banka) which has been fluctuating around $75 \%$ for a period of several years increased to $81.4 \%$ in 2018 (Banks Bulletin, 2019).

The banking system continued to be dominated by foreign-owned banks, and in 2018 it has been $90.2 \%$ in the total banking assets. It is characterized as a system with a very high capital adequacy ratio of $22.9 \%$ at the end of 2018 .

\section{Literature Review}

Cvetkoska and Savić (2021) have made the first bibliometric analysis for DEA in banking in the period from 1986 to 2019, where they analyse articles published in peer-reviewed journals listed in the Scopus database. They have performed an analysis and visualization of bibliometric data related to 791 DEA articles in banking and showed the annual trends of published DEA banking articles, the top journals and authors, citation analysis, and country co-authorship. They have also performed an indepth keyword analysis from all abstracts to identify the research hotspots in different time periods, and provide managerial implications for further research.

Studies regarding the efficiency of commercial banks in North Macedonia and Croatia using the DEA methodology are not very common. There are six studies assessing the relative efficiency of Macedonian commercial banks with DEA: Cvetkoska (2010), Micajkova and Poposka (2013), Naumovska and Cvetkoska (2014), Naumovska and Cvetkoska (2016), Fotova Čiković and Cvetkoska (2017) and Cvetkoska and Fotova Čiković (2020) on one hand, and seven studies regarding the efficiency of the Croatian banking sector: Jemrić and Vujčić (2002), Toçi (2009), Jurčević and Mihelja Žaja (2013), Tuškan and Stojanović (2016), Kordić and Višković (2018), Pavković et al. (2018) and Davidovic,et. al. (2019).

Cvetkoska (2010) has applied a two-stage approach to measure the relative efficiency of Macedonian commercial banks. In the first stage DEA is applied, while in the second stage the analytic hierarchy process $(\mathrm{AHP})$ in order to set restrictions on the weights in the DEA model. In this analysis, 15 Macedonian banks are included and the observed period is from 2005 to 2008 . The average efficiency obtained in the second stage is $84 \%$.

Micajkova and Poposka (2013) measure the technical, pure technical and scale efficiency of 15 Macedonian banks in the period 2008-2011. They use two DEA models: the CCR and the BCC model, which are input-oriented. The inputs are: total deposits received and labour costs while the outputs are loans to banks and customers, and investments. According to the obtained results, Macedonian banks had noted an increase in the average efficiency in the period from 2008 to 2010, and a decrease in 2011. The results of the CCR model show that the average efficiency in 2008 is $59.6 \%$. The average efficiency had increased to $77.9 \%$ in 2010 , and dropped to $69.7 \%$ in 2011 . The number of efficient banks per year is relatively small i.e., only one bank is efficient in 2008, two in 2009 and 2011, and 
three in 2010. As expected, when using the BCC model, the results show a larger number of efficient banks and a higher average efficiency for the whole sector than in the CCR case, implying that the main source of inefficiency is due to scale inefficiencies. The number of efficient units is 4 in 2008,7 in 2009, 6 in 2010 and 4 in 2011.

Naumovska and Cvetkoska (2014) assess the banking efficiency from two perspectives: first, they compare the indicators of efficiency of the Macedonian banking sector with those of the countries of Central and South-Eastern Europe in the period from 2003 - 2012, and second, they estimate the relative efficiency of 14 Macedonian commercial banks in the period from 2007 to 2013 by using the output-oriented CCR DEA model. They use deposits and operating costs as inputs and loans and net interest income as outputs. Based on the obtained results, on average Macedonian banks are most efficient in 2008 (90.3\%) and least efficient in 2012 (79.8\%).

Naumovska and Cvetkoska (2016) measure the relative efficiency of Macedonian banks by using the same variables and time period as in Naumovska and Cvetkoska (2014), but they use another model, i.e., the output-oriented BCC DEA model. In this study, four banks are efficient in the whole observed period. The average efficiency of the Macedonian banking system was the highest in 2008 (93.6\%) and the lowest in 2009 (86.9\%).

Fotova Čiković and Cvetkoska (2017) analyse how efficiency of Macedonian banks has changed over time by using the output-oriented DEA Window analysis model under the VRS assumption. Total deposits (deposits from banks and other clients), interest costs and operating (non-interest) costs (costs for salaries, amortization, administrative costs and other operating costs) are selected as inputs while total loans (issued to banks and other clients), interest revenue and non-interest revenue (fee and commission revenue and other operating revenue) are selected as outputs. The observed period is 2008-2015. Their findings show that the average efficiency of the Macedonian banks in the observed period is $88.7 \%$. Also, they found that the group of large banks has the highest efficiency scores in the Macedonian banking sector.

The most recent DEA study regarding the Macedonian banking sector is by Cvetkoska and Fotova Čiković (2020). They have analysed the efficiency of Macedonian banks in the period of 2007 to 2017, using the output - oriented DEA window analysis model (under VRS assumption). The obtained results show that in the first few years shortly after the global financial crisis, there is a lower efficiency in the majority of banks. The lowest average efficiency for the whole banking sector is achieved in 2011 $(65.25 \%)$ while the highest is achieved in 2007 (84.04\%).

Neralić and Gardijan Kedžo (2019) have made a literature review with studies using the DEA methodology published by authors from Croatia in the period from 1978 to 2018.

Jemrić and Vujčić (2002) have analysed the banking sector in the period from 1995 to 2000 using the input-oriented CCR and BCC models. They have used two approaches: operating and intermediation. In the operating approach inputs are: interest and related costs, commissions for services, gross wages and other administration costs and outputs are: interest revenues, non-interest revenues. In the intermediation approach, inputs are: fixed assets and software, number of employees, total deposits received and outputs are: total loans extended and CNB bills and MoF treasury bills. Their findings show that on average foreign owned banks are more efficient compared with domestic banks and new banks were more efficient than old ones. According to the CCR results, the average efficiency of the banks is $44.5 \%$ and $74.5 \%$ in 1995 and 2000 , respectively while the BCC results show average efficiency $77.7 \%$ and $85.2 \%$ in 1995 and 2000 respectively.

Toçi (2009) uses intermediation approach with deposits and total costs as inputs and loans net of provisions and total revenues as outputs. According to his findings, foreign owned banks succeeded at steadily increasing their intermediation efficiency unlike the domestic banks. Also, in the study of Jurčević and Mihelja Žaja (2013), the intermediation approach is applied with interest expenses, noninterest expenses, and other expenses as inputs and interest incomes, non-interest incomes, and other incomes from business activity as outputs. They have applied is the CCR and BCC outputoriented models and the analysed period is from 2005 to 2010. Based on the obtained results, the 
efficiency had been decreasing since 2007 and the lowest efficiency scores are identified in 2008 when only 10 banks are relative efficient.

Tuškan and Stojanović (2016) use the profitability approach with interest expenses and total operating expenses as inputs, and interest income and total operating income as outputs. They have applied the CCR and BCC output-oriented models in the period from 2008 to 2012. According to the obtained results, the lowest average relative efficiency is achieved in 2012, while the highest in 2008 (according to the CCR model), while BCC-model showed the lowest average efficiency in 2009.

Kordić and Višković (2018) measure the relative efficiency of the Croatian banking sector in one year, 2016. Interest costs, commission and fee costs, general and administrative costs and amortization are selected as inputs, while interest revenues and noninterest revenues i.e., commission and fee revenues are selected as outputs. They have applied the input oriented CCR and BCC model. The results show that 11 out of 24 banks are efficient in 2016. Also, they found no statistically significant difference with regard to the bank ownership.

Pavković et al. (2018) have applied the intermediation approach and use deposits and total equity as inputs, and loans and income from fees and commissions as outputs. They have applied outputoriented CCR and BCC models in the period from 2004 to 2016. They found that large banks are the most efficient by using the BCC model, while the medium-sized banks are the most efficient under the CCR model. In addition, the group of banks that shows the lowest efficiency in Croatia consists of small-sized banks.

The most recent study is by Davidovic et al. (2019). They give new insights regarding the impact of EU accession on bank efficiency. Their study revolves around the efficiency of the Croatian banking industry, analysing the period from 2006 to 2015. They use the intermediation approach, with interest and non-interest expenses as inputs, and interest and non-interest revenues as outputs, and the output-oriented BCC and Andersen-Petersen (1993) models. They have studied the average efficiency scores calculated for the pre-crisis (2006-2009) and crisis periods (2010-2015). Accordingly, the most efficient banks before the crisis were HVB Splitska Bank, Požeška Bank, and Zagrebačka Bank while Credo Bank, Privredna Banka Zagreb and Zagrebačka Bank were the most efficient ones in the crisis period. Kent Bank and Podravska Bank have been identified as the most inefficient ones in the period 2010 to 2015. They have also found that a few commercial banks have maintained their superior efficiency positions over the years (such as Zagrebačka Bank, Privredna Bank Zagreb). In addition, they found that Croatian banks have gained benefits from the EU membership (through lower interest rates for the intra-bank borrowings), and that EU association boosted their efficiency by about $45 \%$.

\section{Methodology and Data}

In DEA it is crucial for the researcher to specify the returns-to-scale (RTS) assumption. This assumption refers to the modification in outputs relating to the change in inputs. The assumption where the augmentation in the inputs reflects a proportional augmentation in the output side is known as the constant-returns-to-scale (CRS). This is not the case with the assumption presented by Banker et al. (1984), i.e., the variable-returns-to-scale (VRS). The VRS implies inputs' modification to not necessarily result in proportional modification within the outputs. Banker and Park (2021) argue that VRS is the most extensively used assumption which makes sense from the economic point of view, and that the VRS estimator exhibits much quicker convergence.

In our reviewed literature, the BCC DEA model has been mostly used in the studies regarding the Macedonian banking sector, whereas both CCR and BCC models have been used in the studies regarding the Croatian banking sector. To measure the variables, we apply the operating (incomebased) approach as in Banker et al. (2010). According to Leightner and Lovell (1998), in this approach the final objective of banks as business units is to generate revenue from the total cost that is incurred to run the business (Banker et al., 2010, p.1454). Therefore, we follow Banker et al. (2010) in the selection of inputs and outputs. We use two inputs: interest expense and other operating expense (fee and commission expense, staff expense, administrative costs, depreciation, and other expenses), and 
two outputs: interest revenue and other operating (non-interest) revenue (fee and commission revenue and other revenue). Accordingly, we follow Banker et al. (2010) in the selection of DEA model (as in their first stage), the output-oriented BCC DEA model based on which banks will thrive to maximize the outputs (revenues) by using the given level of inputs (costs).

The envelopment form of the output-oriented BCC DEA model is given in (1) - (5), (Cooper et al., 2007):

$$
\begin{array}{cc} 
& \max _{\eta_{B}, \lambda} \eta_{B} \\
\text { subject to } \quad X \lambda \leq x_{o} & \\
\eta_{B} y_{o}-Y \lambda \leq 0_{(3)} \\
e \lambda=1_{(4)} \\
\lambda \geq 0_{(5)}
\end{array}
$$

where $\eta_{B}$ is a scalar. The input data for $\operatorname{DMUj}(\mathrm{j}=1, \ldots, \mathrm{n})$ are $\left(x_{1 j}, x_{2 j}, \ldots, x_{m j}\right)$, and the output data are $\left(y_{1 j}, y_{2 j}, \ldots, x_{s j}\right)$; the data set is given by two matrices $X$ and $Y$, where $X$ is the input data matrix, and $Y$ is the output data matrix, $\lambda$ is a column vector and all its elements are non-

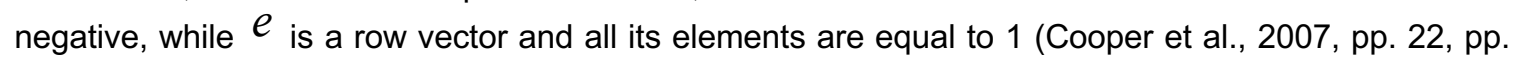
91-92, Cvetkoska and Barišić, 2017, pp. 33-34). For one DMU to be BCC relative efficient two conditions need to be satisfied: 1 ) the efficiency score to be equal to 0 and 2) all slacks to be equal to 0 . See more about the BCC DEA model in Banker et al., (1984) and Cooper et al. (2007), pp. 90-94.

First, we will apply the output-oriented BCC DEA model, and if unusual results are obtained, e.g. if it appears that the banks that are not good performers are on the top and vice versa, then we will apply the Banker and Gifford (1988) super-efficiency procedure. To identify outliers that might influence the efficiency results, Banker and Gifford (1988) proposed a super-efficiency procedure. This procedure works as follows. In the assessment of the DMUs efficiency there will not be taken into consideration all of them, but one different unit will be dropped as this procedure is initiated every time. After obtaining the relative efficiency scores, the score of DMU that is dropped will be estimated against the DMUs that were identified as relative efficient in the previous step. Based on the evidence provided by Banker and Chang (2006), the DMU with a super-efficiency result that exceeds 1.2, should be identified as an outlier. After identifying the outliers, they will be analysed in detail in order to decide whether to remove an outlier. If an outlier(s) is/are removed (if any), the BCC DEA model will be rerun. By using the same procedure as in Banker and Gifford (1988), Andersen and Petersen (1993) have suggested ranking of DMUs identified as relative efficient to be based on the super-efficiency result, which is not to use this result for the same purpose as this procedure was introduced. Banker and Chang (2006) have explored how the Banker and Gifford (1988) procedure performs in both cases (to identify outliers and to rank relative efficient DMUs) by using simulation. Based on their evidence, this procedure is not adequate to rank DMUs that are relative efficient, as was suggested in Andersen and Petersen (1993). However, when it is used for identifying and removing outliers, the efficiency scores reflect better the factual situation than the efficiency scores obtained by the BCC DEA model.

The data for the inputs and outputs are collected manually (by hand) from the banks' official and published financial reports (in the case of Macedonian commercial banks) and from the Croatian National Bank's Bank Bulletin (in the case of Croatian commercial banks). The observed period is 5 years (from 2015-2019). The year 2020 is not taken into account due to the lack of available statements. We use a balanced panel data for both bank samples. There are 15 banks operating in the Macedonian banking system in 2019. We have excluded the Macedonian Bank for Development and Promotion from the analysis because it is a state-owned bank whose nature of operations does not correspond to those of commercial banks (it does not engage in collecting deposits), and its 
specific development function in the sector. In addition, there is no available data for Eurostandard Bank AD Skopje in 2019. In August 2020, the National Bank revoked the license for establishment and operation of Eurostandard Banka AD Skopje, due to the non-compliance with the minimum legal requirements for bank operations. Therefore, we consider 13 commercial Macedonian banks for each year, i.e. a total of $65\left(=13^{\star} 5\right)$ Macedonian bank-year observations. In the Croatian banking system, there are 20 commercial banks operating at the end of 2019 and all of them are considered in our analysis so that there are 20 Croatian commercial banks for each year, i.e. a total of $100\left(=20^{*} 5\right)$ Croatian bank-year observations.

The results are obtained by using the MaxDEA 8 Ultra software (licensed version)1. They are presented and analyzed in the next section.

\section{Results and Analysis}

\section{The efficiency of the banking system in North Macedonia}

After applying the output-oriented BCC DEA model, the efficiency results are obtained and unusual results are identified for one bank from the group of small banks (Capital Bank AD Skopje). The bank appears to be relative efficient in the whole period, although this does not correspond to the real situation (the bank has operated quite unconsistently, operating with small profit in 2015 and 2018, whereas noting big loan impairment losses in 2017 and operating with losses in 2013 and 2019 as well). Therefore, the super-efficiency procedure proposed by Banker and Gifford (1988) was applied. According to the applied super-efficiency model, no feasible solution was found for Capital Banka AD Skopje (in the whole analyzed period) which means that this bank is not comparable with its peers. Because this bank is not comparable with any other bank in the Macedonian banking sample, it is compared with itself and the BCC algorithm identifies as efficient.

Besides Capital Banka AD Skopje, TTK Banka AD Skopje has no feasible solution in two years (2016 and 2017) and in the remaining years the super-efficiency result is 2.3171, 1.4319 and 1.7252 in 2015 , 2018 and 2019 respectively. These results are significantly higher than the one proposed by Banker and Chang (2006) which is 1.2. Therefore, we have excluded TTK Banka AD Skopje from the further evaluation. After removing these two commercial banks, we have rerun the output-oriented BCC DEA model. The descriptive statistics for the Macedonian banks for the whole observed period (a total of 55 bank-year observations) is shown in Table 1 while the obtained results are shown in Table 2.

As we can see from Table 2, four banks (Komercijalna Banka AD Skopje, NLB Banka AD Skopje, Silk Road AD Banka Skopje and Stopanska Banka AD Skopje) are relative efficient in the whole observed period, while three banks (Halkbank AD Skopje, Ohridska Banka AD Skopje and ProCredit Banka AD Skopje) are relative inefficient in the whole analyzed period of five years. According to the classification by the National Bank of the Republic of North Macedonia, there are three groups of banks based on their size (measured by total assets): small, medium and large. Three of the relative efficient banks (Komercijalna Banka AD Skopje, NLB Banka AD Skopje, and Stopanska Banka AD Skopje) belong to the group of large banks. Halkbank AD Skopje is identified as relative inefficient, but this bank has been investing heavily in new technologies in this period and has been committed to its growth strategy (it has introduced new platform for e-banking in 2015; introduced its mobile applications for e-banking for individuals and legal entities in 2017). The positive effects of these investments can be seen in the upcoming period. ProCredit Banka AD has noted a dramatic loss of clients, deposit accounts and number of employees and branches in 2017 and a smaller decrease of them in 2018 as opposed to 2016. Ohridska Banka AD Skopje has been acquired by the Steiermarkische Sparkasse Group (already active in the Macedonian banking market) in 2019, so further increase in efficiency is to be expected.

\footnotetext{
${ }^{1}$ Available at: http://maxdea.com/MaxDEA.htm
} 
Table 1. Summary Statistics for Macedonian Banks

\begin{tabular}{lllll}
\hline & $\begin{array}{l}\text { Interest } \\
\text { Expense }\end{array}$ & $\begin{array}{l}\text { Other Operating } \\
\text { Expense }\end{array}$ & $\begin{array}{l}\text { Interest } \\
\text { Revenue }\end{array}$ & $\begin{array}{l}\text { Other Operating } \\
\text { Revenue }\end{array}$ \\
\hline Mean & 351103 & 1401188 & 1663551 & 702653 \\
Standard Error & 34343 & 147684 & 188693 & 90217 \\
Median & 278721 & 901580 & 1040009 & 362724 \\
Standard Deviation & 254691 & 1095256 & 1399381 & 669064 \\
Kurtosis & 0.57 & 0.74 & -0.78 & 0.58 \\
Skewness & 1.01 & 1.23 & 0.85 & 1.28 \\
Range & 1062283 & 4284237 & 4266362 & 2596021 \\
Minimum & 68337 & 278877 & 243498 & 103964 \\
Maximum & 1130620 & 4563114 & 4509860 & 2699985 \\
Sum & 19310664 & 77065337 & 91495289 & 38645899 \\
Count & 55 & 55 & 55 & 55 \\
\hline \multicolumn{5}{r}{ Source: Authors' calculations }
\end{tabular}

The highest number of relative efficient banks is in 2015 (8 banks), while the lowest is in 2018 (4 banks). The lowest number of relative efficient banks in 2018 can be related with the decline of the interest income of Macedonian banks. The increased volume of activities of banks in 2018 was not enough to support the growth of interest income. Banks managed to offset some of that decline through downsizing on the expenditure side, but that space is getting narrower and narrower (Financial Stability Report for the Republic of North Macedonia in 2018, 2019).

Table 2. Efficiency Scores for Commercial Banks in North Macedonia

\begin{tabular}{|c|c|c|c|c|c|}
\hline \multirow[b]{2}{*}{ Bank } & \multicolumn{5}{|c|}{ Efficiency Score (2015-2019) } \\
\hline & 2015 & 2016 & 2017 & 2018 & 2019 \\
\hline $\begin{array}{l}\text { Centralna Kooperativna Banka } \\
\text { AD Skopje }\end{array}$ & 1 & 1 & 0.9878 & 0.8274 & 1 \\
\hline Halkbank AD Skopje & 0.8762 & 0.8141 & 0.7366 & 0.7680 & 0.7587 \\
\hline Komercijalna Banka AD Skopje & 1 & 1 & 1 & 1 & 1 \\
\hline NLB Banka AD Skopje & 1 & 1 & 1 & 1 & 1 \\
\hline Ohridska Banka AD Skopje & 0.8949 & 0.7918 & 0.7721 & 0.7629 & 0.5642 \\
\hline ProCredit Banka AD Skopje & 0.8587 & 0.7971 & 0.7915 & 0.7181 & 0.7647 \\
\hline Silk Road Banka AD Skopje & 1 & 1 & 1 & 1 & 1 \\
\hline $\begin{array}{l}\text { Sparkasse Banka Makedonija } \\
\text { AD Skopje }\end{array}$ & 1 & 1 & 1 & 0.9887 & 0.9289 \\
\hline Stopanska Banka AD Bitola & 1 & 0.8696 & 0.8006 & 0.7653 & 0.8908 \\
\hline Stopanska Banka AD Skopje & 1 & 1 & 1 & 1 & 1 \\
\hline Uni Banka AD Skopje & 1 & 0.8369 & 1 & 0.7950 & 0.7322 \\
\hline Number of Efficient Banks & 8 & 6 & 6 & 4 & 5 \\
\hline Minimum & 0.8587 & 0.7918 & 0.7366 & 0.7181 & 0.5642 \\
\hline Maximum & 1 & 1 & 1 & 1 & 1 \\
\hline Standard Deviation & 0.0582 & 0.0952 & 0.1137 & 0.1203 & 0.1497 \\
\hline
\end{tabular}


In Figure 1 we present the average relative efficiency of the Macedonian banking sector by years, and the average relative efficiency of the Macedonian banking sector in the whole period is 0.9108 i.e. $91.08 \%$.

Figure 1. Average Efficiency for the Macedonian Banking Sector

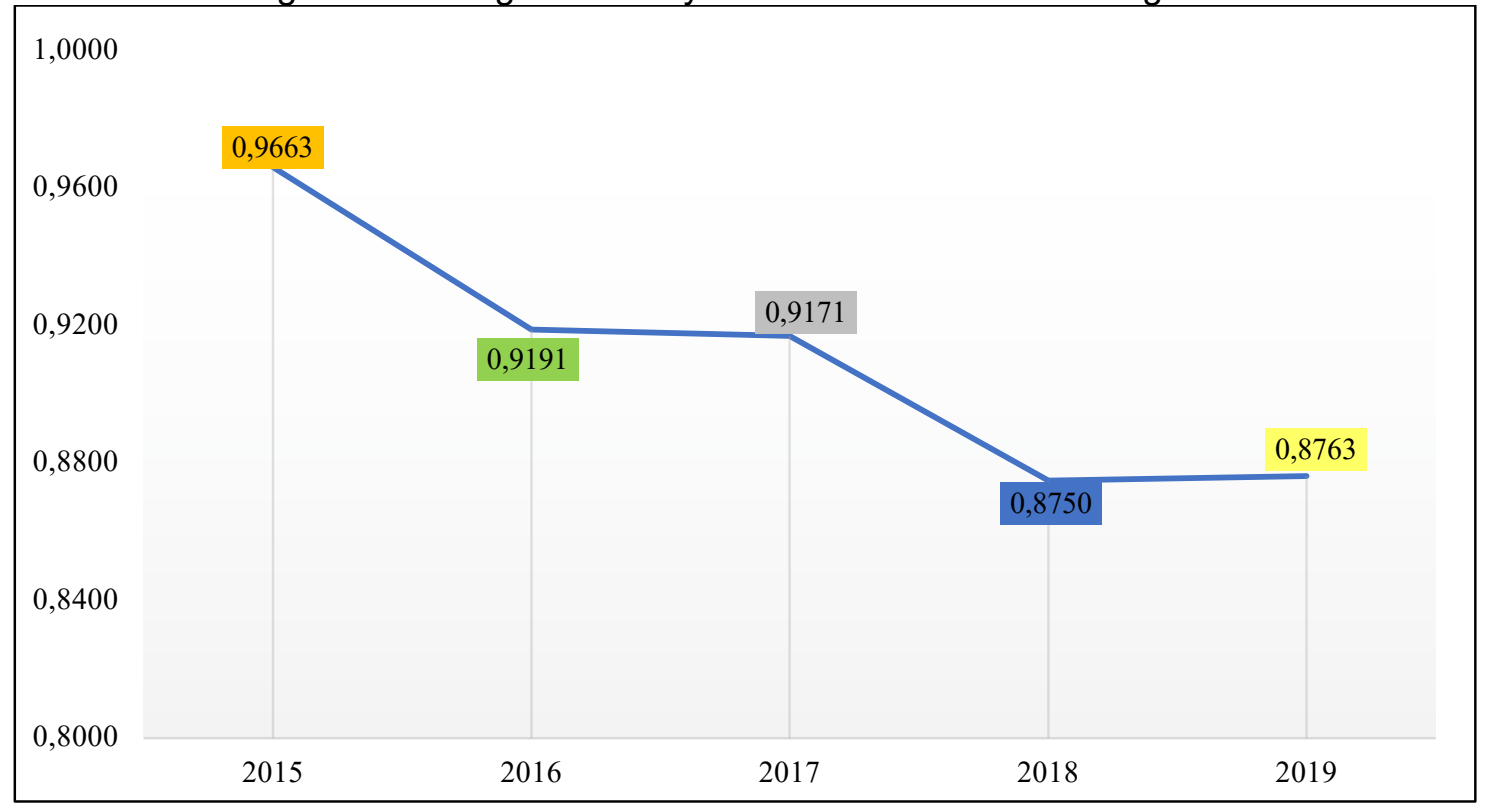

Source: Authors' calculations

In Figure 2, both the constant returns-to-scale (CRS) and the variable returns-to-scale (VRS) frontiers are presented plotted with original data for one input (interest expense) and one output (interest revenue) for 2019. The variable interest expense is on the horizontal axis whereas the variable interest revenue is on the vertical axis. Based on Figure 2, Stopanska Banka AD Skopje comprises the CRS frontier, while Stopanska Banka AD Skopje and Silk Road Banka AD Skopje comprise the VRS frontier. 
Figure 2. CRS and VRS Frontier for Macedonian Banks (one input-output case)

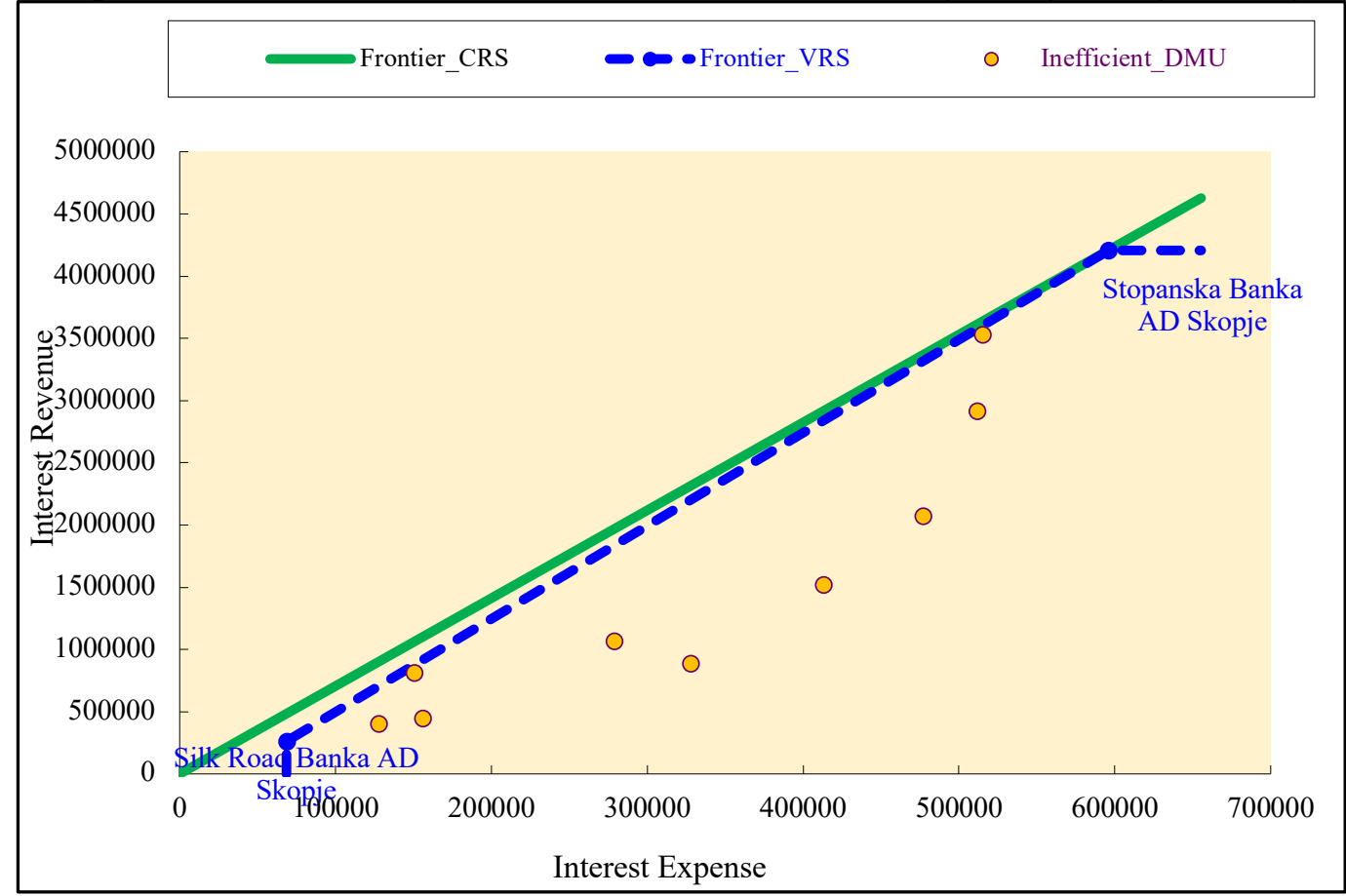

Source: Authors' calculations

The authors have further analyzed three banks, i.e. Ohridska Banka AD Skopje (that is relative inefficient in the whole observed period and its efficiency is decreasing in every year that follows), Sparkasse Banka Makedonija AD Skopje (that was efficient in the first three years, and then it decreased its efficiency) and Uni Banka AD Skopje (that shows variable efficiency results) (Figure 3).

Ohridska Banka AD Skopje has noted high impairment costs of financial assets at the end of 2016 year, which includes the provisions for growth of the portfolio, as well as additional reservations at the discretion of the relevant bodies of the bank. Sparkasse Bank Makedonija AD Skopje has implemented a process of cleaning the non-performing loan portfolio, especially in the corporate segment, i.e. increasing its quality, with the share of total non-performing loans being decreased from $8.3 \%$ to $7.0 \%$ in 2017. In 2019, Steiermärkische Sparkasse Group has signed an agreement with the French group Societe Generale for the acquisition of up to $100 \%$ of the shares of Ohridska Banka AD Skopje. Uni Banka AD Skopje has shown rather inconsistent efficiency results, being relative efficient in 2015 and 2017 and being relative inefficient in 2016, 2018 and 2019 (with results of 0,836; 0,795 and 0,732 respectively). These results could be interpreted by analysis of the banks' activities and position in this period. Uni Banka AD Skopje has been growing steadily in this period, and the total assets of the Bank registered the highest growth in the banking sector in the amount of $26 \%$ in 2018 . The Bank has undertaken a pioneering step on the Macedonian financial market and issued the first perpetual bond in 2019 and obtained a decree for a systemically important bank. Thus, it is safe to assume that these inefficiency scores are a result of heavy investments in growth.

Besides the fact that DEA methodology can handle multiple inputs and multiple outputs, it also provides benchmarks for inefficient units as well as targets for improvement of the identified inefficiency.

For example, there are two benchmarks for Uni Banka AD Skopje in 2019, and these are Centralna Kooperativna Banka AD Skopje (with $\lambda=0.66286$ ) and NLB Banka AD Skopje (with $\lambda=0.3371357$ ). In order to improve its efficiency Uni Banka AD Skopje needs to decrease the interest expense to 258.360 (in 000s of Macedonian Denars) and increase the interest revenue and other operating revenue to 1.460 .474 and 661.491 (in 000s of Macedonian Denars) respectively. 
Figure 3. Efficiency Change Over Time for Three Macedonian Banks

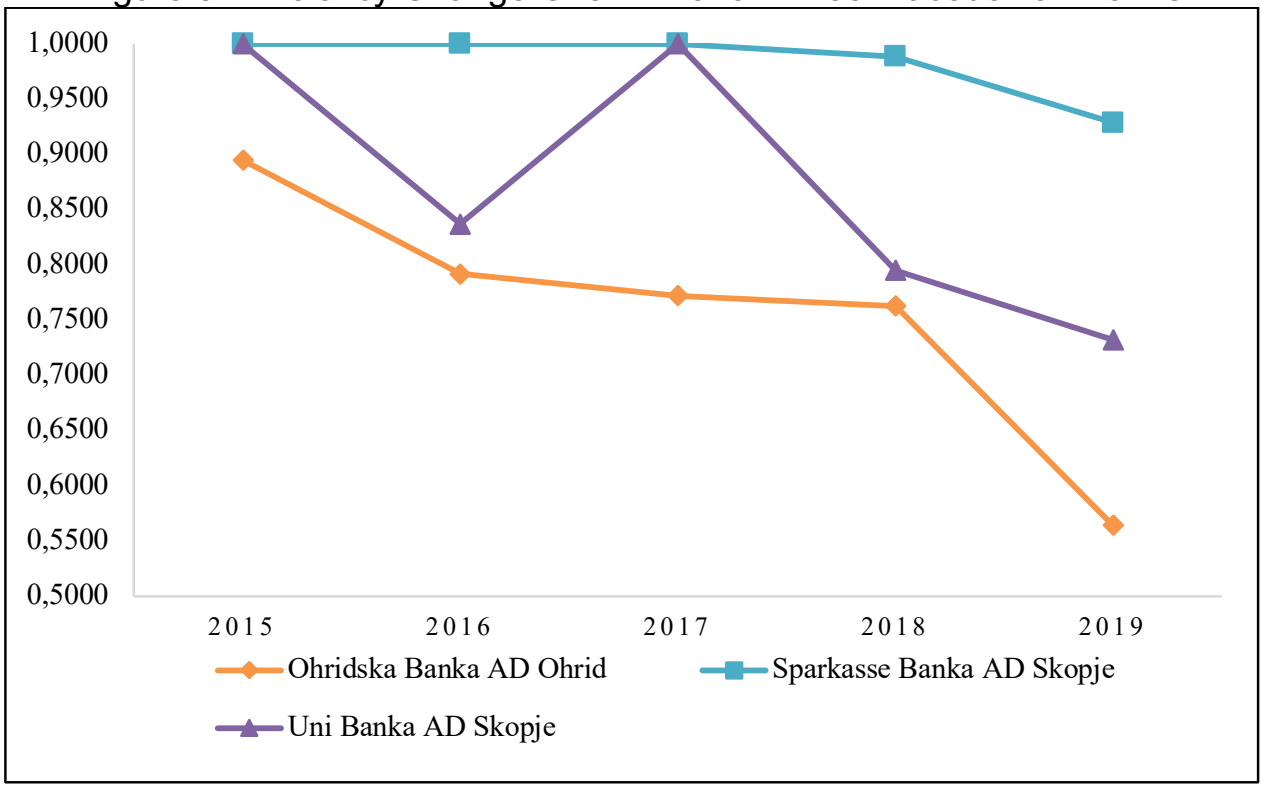

Source: Authors' calculations

The efficiency of the banking system in Croatia

After applying the output-oriented BCC DEA model, unusual results were identified for Samoborska Banka d.d., which was efficient in the whole analyzed period, but these does not reflect the real situation because this bank operated with loses from 2015 to 2019. In the super-efficiency model, no feasible solution was found for this bank and therefoore it is excluded from further analysis and the BCC output-oriented model is rerun. The summary statistics for the Croatian banks for the whole observed period (a total of 95 bank-year observations) is presented in Table 3, while the effiicency scores are shown in Table 4.

Table 3. Summary Statistics for Croatian Banks

\begin{tabular}{lllll} 
& $\begin{array}{l}\text { Interest } \\
\text { Expense }\end{array}$ & $\begin{array}{l}\text { Other } \\
\text { Operating } \\
\text { Expense }\end{array}$ & $\begin{array}{l}\text { Interest } \\
\text { Revenue }\end{array}$ & $\begin{array}{l}\text { Other Operating } \\
\text { Revenue }\end{array}$ \\
\hline Mean & 202327 & 503384 & 734506 & 278478 \\
Standard Error & 46462 & 69313 & 119333 & 43667 \\
Median & 44031 & 86538 & 127650 & 40065 \\
Standard Deviation & 452853 & 675581 & 1163113 & 425613 \\
Kurtosis & 23.63 & 1.72 & 5.48 & 4.11 \\
Skewness & 4.58 & 1.56 & 2.32 & 1.95 \\
Range & 3075699 & 2988692 & 5672099 & 2199208 \\
Minimum & 6543 & 36466 & 32157 & 6601 \\
Maximum & 3082242 & 3025158 & 5704256 & 2205809 \\
Sum & 19221100 & 47821472 & 69778031 & 26455377 \\
Count & 95 & 95 & 95 & 95 \\
\hline
\end{tabular}


As we can see from Table 4, eight banks (Banka Kovanica d.d., Erste \& Steirmaerkische Bank d.d., Hrvatska Poštenska Banka d.d., Istarska Kreditna Banka Umag d.d., Privredna Banka Zagreb d.d., Reiffeisenbank Austria d.d., Slatinska Banka d.d., and Zagrebačka Banka d.d.) are relative efficient in the whole observed period, while five banks (Addiko Bank d.d., Agram Banka d.d., Croatia Banka d.d., Podravska Banka d.d., and Sberbank d.d) are relative inefficient in the analyzed period of five years. These five relative inefficient banks are mostly small banks, with Sberbank d.d. as an exception. Sberbank d.d. has experienced severe impact on its efficiency and profitability during the Agrokor Group crisis, since it was the main bank that financed Agrokor's operations, i.e. in 2014, Agrokor group and Sberbank d.d. announced EUR 600 million syndicated long-term loan facility. As for the identified eight relative efficient banks, they include the group of large banks plus Banka Kovanica d.d., Istarska Kreditna Banka Umag d.d., and Slatinska Banka d.d., that were using the rather favourable economic prerequisites, such as high liquidity of financial system, economic recovery and growing business optimism. Istarska Kreditna Banka Umag d.d. has announced its 2016-2020 Strategic Business Plan period and improved its position on the Croatian financial market in this period.

In four years, there are eleven relative efficient banks, while in 2016 there are ten relative efficient banks. In Figure 4 is presented the average relative efficiency for the Croatian banking sector by years, and the average relative efficiency of the Croatian banking sector in the whole period is 0.9094 i.e., $90.94 \%$.

The high percentage of efficient banks in the whole observed period (10 efficient banks in 2016 and 11 efficient banks in 2015, 2017, 2018 and 2019) can be explained with Croatia's exit from the 6 years of recession in 2015. Furthermore, in 2016, banks' profitability improved after the losses of 2015 caused by conversion costs of loans (in Swiss francs into loans in euro) in 2015 which also improved the quality of housing loans and loan portfolio (Banks Bulletin, 2017). After six year period of decrease and stagnation, bank assets increased considerably in 2018 and reached their record high (Banks Bulletin, 2019).

Table 4. Efficiency Scores for Commercial Banks in Croatia

\begin{tabular}{|c|c|c|c|c|c|}
\hline \multirow[b]{2}{*}{ Bank } & \multicolumn{5}{|c|}{ Efficiency Score (2015-2019) } \\
\hline & 2015 & 2016 & 2017 & 2018 & 2019 \\
\hline Addiko Bank d.d. & 0.6230 & 0.7493 & 0.8027 & 0.7595 & 0.8513 \\
\hline Agram Banka d.d. & 0.8235 & 0.8288 & 0.8414 & 0.9044 & 0.9669 \\
\hline Banka Kovanica d.d. & 1 & 1 & 1 & 1 & 1 \\
\hline Croatia Banka d.d. & 0.8489 & 0.8162 & 0.6735 & 0.6645 & 0.6900 \\
\hline Erste\&Steirmaerkische Bank d.d. & 1 & 1 & 1 & 1 & 1 \\
\hline Hrvatska Poštanska Banka d.d. & 1 & 1 & 1 & 1 & 1 \\
\hline Imex Banka d.d. & 1 & 0.8698 & 0.7374 & 0.7434 & 0.7143 \\
\hline $\begin{array}{l}\text { Istarska Kreditna Banka Umag } \\
\text { d.d. }\end{array}$ & 1 & 1 & 1 & 1 & 1 \\
\hline J\&T Banka d.d. & 0.6592 & 0.6820 & 1 & 1 & 1 \\
\hline Karlovačka Banka d.d. & 0.7428 & 1 & 1 & 1 & 1 \\
\hline KentBank d.d. & 1 & 0.7290 & 0.6991 & 0.7862 & 0.7967 \\
\hline OTP Banka d.d. & 0.9263 & 1 & 1 & 1 & 1 \\
\hline Partner Banka d.d. & 1 & 0.9113 & 0.7572 & 0.7840 & 0.7092 \\
\hline Podravska Banka d.d. & 0.7626 & 0.8735 & 0.7312 & 0.7766 & 0.7912 \\
\hline Privredna Banka Zagreb d.d. & 1 & 1 & 1 & 1 & 1 \\
\hline Reiffeisenbank Austria d.d. & 1 & 1 & 1 & 1 & 1 \\
\hline Sberbank d.d. & 0.8487 & 0.9025 & 0.8475 & 0.8275 & 0.9380 \\
\hline Slatinska Banka d.d. & 1 & 1 & 1 & 1 & 1 \\
\hline
\end{tabular}




\begin{tabular}{llllll}
\hline Zagrebačka Banka d.d. & 1 & 1 & 1 & 1 & 1 \\
\hline Number of Efficient Banks & 11 & 10 & 11 & 11 & 11 \\
Minimum & 0.6230 & 0.6820 & 0.6735 & 0.6645 & 0.6900 \\
Maximum & 1 & 1 & 1 & 1 & 1 \\
Standard Deviation & 0.12892 & 0.10793 & 0.12751 & 0.11916 & 0.11763 \\
\hline \multicolumn{5}{l}{} \\
Source: Authors' calculations
\end{tabular}

Figure 4. Average Efficiency for the Croatian Banking Sector

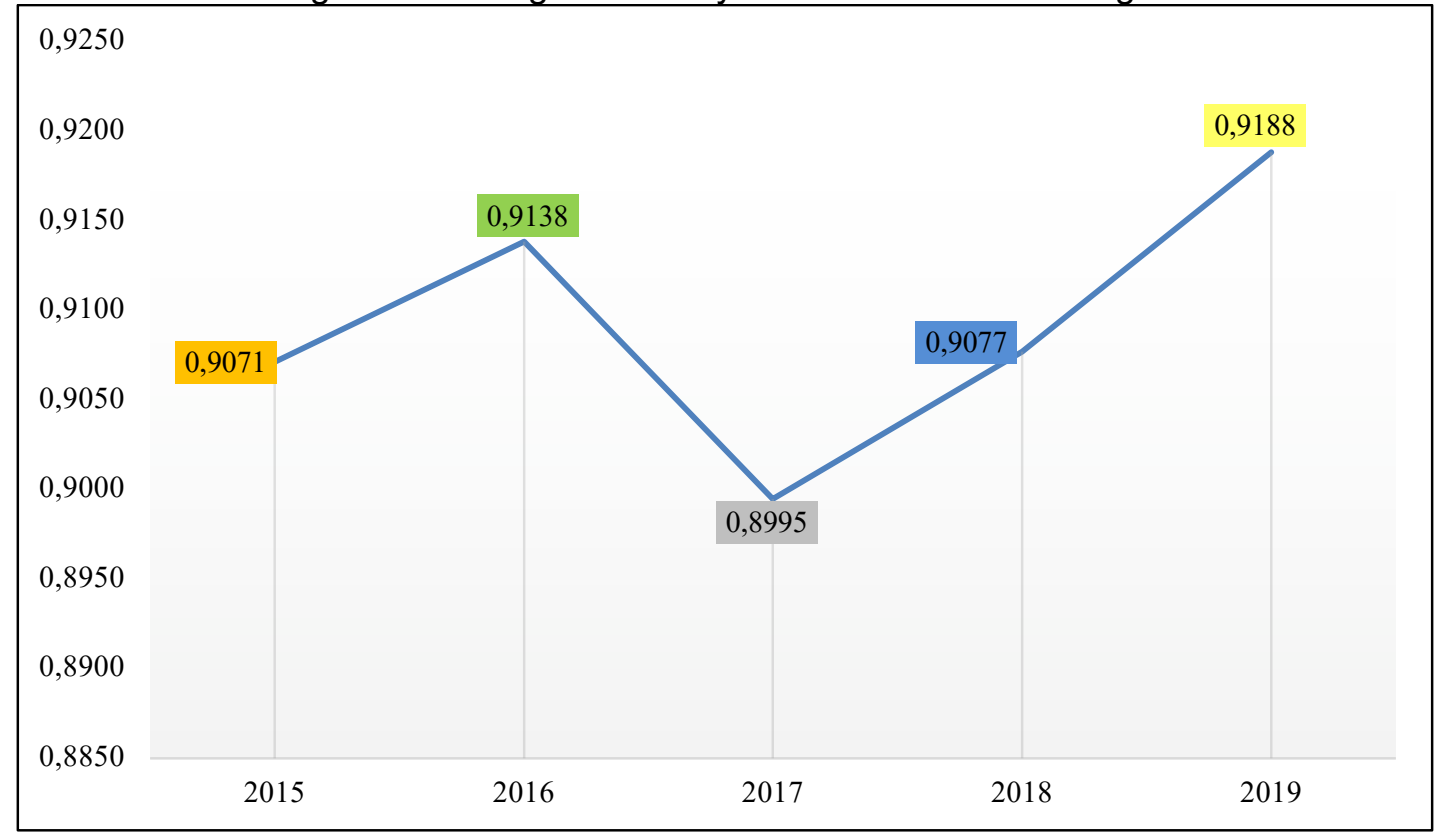

Source: Authors‘ calculations

In Figure 5 we present both the CRS and VRS frontiers plotted with original data for one input (interest expense) and one output (interest revenue) for 2019, so that on the horizontal axis is the variable interest expense while on the vertical axis is the variable interest revenue. We have added the names for efficient banks in both frontiers (4 banks comprise the VRS, while 2 banks comprise the CRS frontier). Based on Figure 5, Istarska Kredtna Banka Umag d.d., OTP Banka d.d., Privredna Banka Zagreb d.d., and Zagrebačka Banka d.d. comprise the VRS frontier, while Istarska Kredtna Banka Umag d.d., OTP Banka d.d. comprise the CRS frontier.

The authors have also analyzed three banks, i.e., Agram Banka d.d. (that is relative inefficient in the whole observed period and its efficiency is increasing in every year that follows), Imex Banka d.d. (that was efficient in the first analyzed year, and then it decreased the efficiency) and KentBank d.d. (that shows variable efficiency results) (Figure 6).

Each of these three banks is part of the small banks' group. Agram Banka d.d. has been slowly increasing the balance sheet ever since 2015. The bank has suffered a lot in the Agrokor Group collapse due to the insignificant market share and by mostly limiting itself to lending to Agrokor. Namely, this bank has been called Kreditna Banka Zagreb d.d. up until 2019 when it was renamed to Agram Banka d.d., and it was founded in 1994 by the ex-owner and founder of Agrokor Group, who wanted its own bank to participate in the growth and development of the Agrokor Group. 
Figure 5. CRS and VRS Frontier for Croatian Banks (one input-output case)



Source: Authors' calculations

In November 2015, Imex Banka d.d. has changed the previous business model, and accordingly the business strategy. The essence of a changed business model refers to the reduction of the Bank's risk profile, the reduction of concentration risk with primary orientation and emphasis on the growth of the citizen portfolio. This business strategy was updated in November 2016 for the period 2016-2021. Imex Banka d.d. has been struggling with losses in this whole analyzed period, with the exception of year 2019. The bank has also faced high costs of impairment and provisions as a result of "clearing" the balance sheet.

KentBank d.d. has been acquitted by the Süzer Group in 2011. Ever since, the bank has been heavily investing, implementing modern technologies and expanding. In 2015, two new branches have been opened and the capital increased by EUR 5 million. In 2017, new Internet and Mobile banking was introduced, a representative office in Turkey was opened and a subordinated loan of EUR 3.5 million was issued. In the analysed period, KentBank d.d. has invested in new employees as well. KentBank d.d. has managed to increase its assets in 89\% from 2015 to 2019.

KentBank d.d has three benchmarks: Banka Kovanica d.d. (with $\lambda=0.782163$ ), Istarska Kreditna Banka Umag d.d. (with $\lambda=0.193179$ ), and OTP Banka d.d (with $\lambda=0.0 .024658$ ). In order to improve its efficiency, KentBank d.d. needs to increase the interest revenue to 111.511 (in 000s of Croatian kuna) and other operating revenue to 26.813 (in 000s of Croatian kuna) respectively. 
Figure 6. Efficiency Change Over Time for Three Croatian Banks

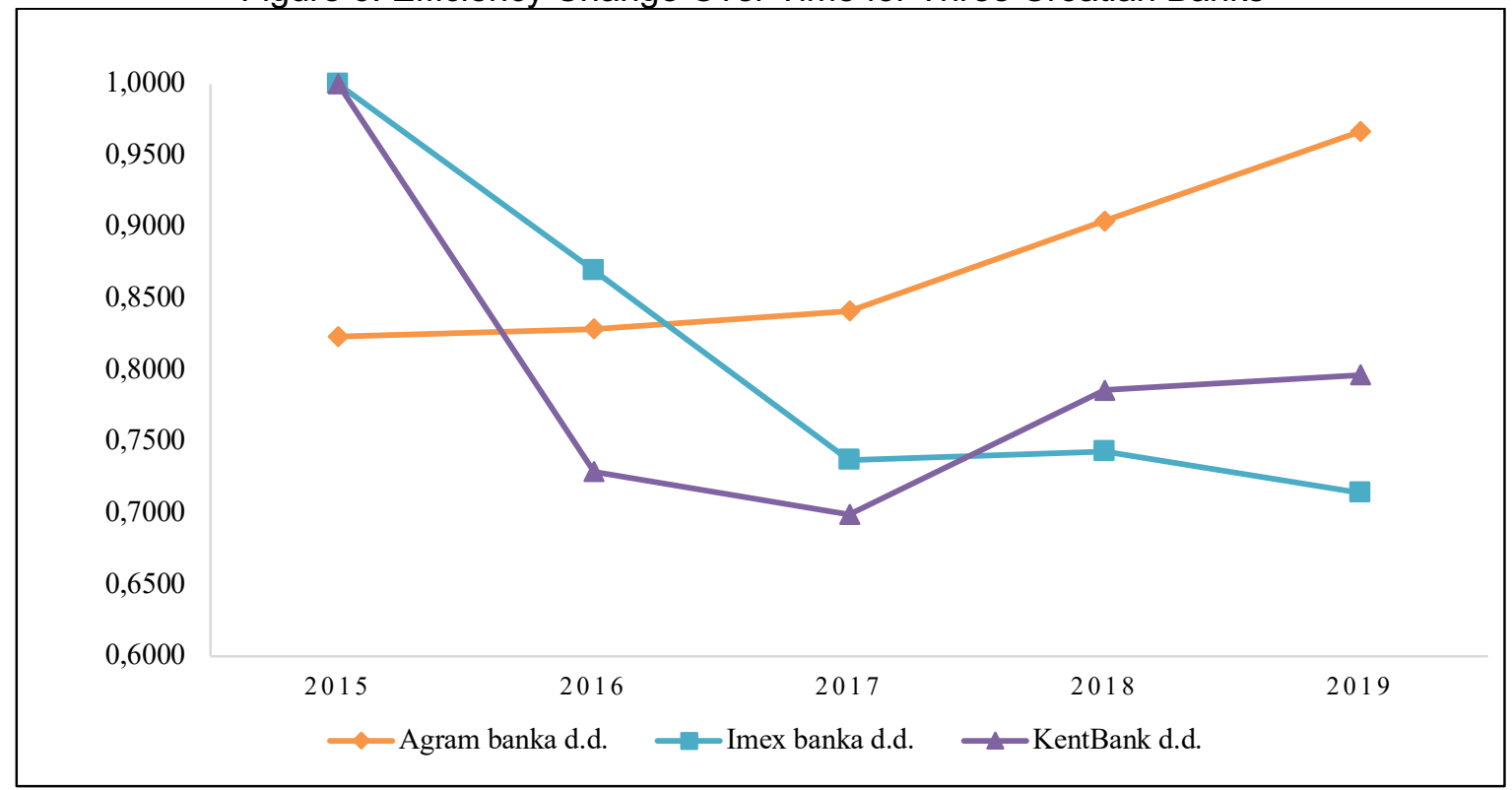

Source: Authors‘ calculations

\section{Comparison of the efficiency scores of the Macedonian and Croatian banking sectors}

In this paper, we measure the relative efficiency of commercial banks in two developing countries in Europe i.e. the Republic of North Macedonia and the Republic of Croatia from the operating (incomebased) perspective by using DEA. The observed period is five years (2015-2019) and we use a balanced panel data for both samples. More precisely we consider 11 Macedonian bank-year observations (in total 55 Macedonian bank-year observations) and 19 Croatian bank-year observations (in total 95 Croatian bank-year observations).

According to the obtained results, 4 Macedonian (36.3\%) and 8 Croatian (42.1\%) banks are relative efficient for the whole observed period. In both countries, most of the relative efficient banks for the whole observed period belong in the group of large banks as in Naumovska and Cvetkoska (2016) and Fotova Cikovic and Cvetkoska (2017) for the Macedonian banking sector, and as in Pavković et al. (2018) for the Croatian banking sector. More precisely, in the Republic of North Macedonia, 3 of the relative efficient banks for the whole observed period are in the group of large banks, while in Croatia, 5 of the of the relative efficient banks for the whole observed period are in the group of large banks.

Besides, 3 Macedonian (27.2\%) and 5 Croatian (26.3\%) are relative inefficient in the whole observed period. In the Republic of Croatia most of the relative inefficient banks (4) for the whole observed period are in the group of small banks (as in Pavkovic et al., 2019) while in North Macedonia the relative inefficient banks are from the middle-sized banks' group. Interestingly, the one bank representing the small banks' group (Silk Road Bank AD Skopje) has been relative efficient in the whole observed period, while the other small banks have been excluded from the analysis (explained in 5.1).

On average, the minimal relative efficiency for the Macedonian banking sector is achieved in the last observed year, 2019 (56.42\%) while in Croatia in the first observed year, 2015 (62.30\%).

Both sectors, on average show high relative efficiency for the whole observed period, i.e., $91.08 \%$ and $90.94 \%$ for the Macedonian and Croatian banking sector, respectively. 


\section{Conclusion}

Efficiency is an indicator of successful operating of organizations and its measurement can be performed by applying parametric and non-parametric methodologies. In this paper we have focused on the measuring the relative efficiency of commercial banks in two developing countries (North Macedonia and Croatia) under the operating (income-based) approach by using the leading nonparametric methodology DEA. This is the first study that analyzes the both sectors based on the Scopus search in title-abstract-keywords with the fields: DEA and commercial banks and North Macedonia and Croatia. We follow Banker et al. (2010) in the selection of variables (two inputs: interest expense and other operating expense, and two outputs: interest revenue and other operating revenue) under the operating (income-based) approach and the model (output-oriented BCC DEA model as in their first stage). The observed period is five years (2015-2019) and we use balanced panel data for both samples.

First, we have run the output-oriented BCC model on 13 Macedonian bank-year observations (total 65 Macedonian bank-year observations) and 20 Croatian bank-year observations (total 100 Croatian bank-year observations) and we have identified unusual results. In order to identify whether there are outliers present in the sample, we have applied the super-efficiency procedure as proposed by Banker and Gifford (1988), and we have excluded 2 Macedonian and 1 Croatian bank, and rerun the outputoriented BCC model on 11 Macedonian bank-year observations (total 55 Macedonian bank-year observations) and 19 Croatian bank-year observations (total 95 Croatian bank-year observations).

We present results for the efficiency of each commercial bank, the average efficiency of both banking systems which is higher in North Macedonia, and we provide analysis for few banks identified with increasing, decreasing or variable results in the observed period. Also, we show how inefficient bank can improve its efficiency. In addition, we provide comparison of the efficiency results for both sectors. Those results provide valuable information for the bank management and the regulatory bodies.

In our future research, we plan to include the period before, during and after the pandemic due to the virus COVID-19 and to investigate the determinants of bank efficiency in these developing countries.

\section{References}

Andersen, P. and Petersen, N. (1993), "A procedure for ranking efficient units in data envelopment analysis", Management Science 39, 1261-1264. https://doi.org/10.1287/mnsc.39.10.1261

Banker, R. D. and Gifford, J. L. (1988), A Relative Efficiency Model for the Evaluation of Public Health Nurse Productivity, Pittsburgh: School of Urban and Public Affairs, Carnegie Mellon University Banker, R.D., and Chang, H. (2006), „The super-efficiency procedure for outlier identification, not for ranking efficient units“, European Journal of Operational Research, 175(2), 1311-1320. https://doi.org/10.1016/j.ejor.2005.06.028

Banker, R.D., and Park, H.U. (2021). "Three-Stage Approach to Analyze Managerial Ability", Data Envelopment Analysis Journal, Vol. 5: No. 1, pp. 27-54. http://dx.doi.org/10.1561/103.00000034

Banker, R.D., Chang, H. and Lee, S. (2010), „Differential impact of Korean banking system reforms on bank productivity“, Journal of Banking and Finance, 34 (7), pp. 1450-1460, https://doi.org/10.1016/j.jbankfin.2010.02.023.

Banker, R.D., Charnes, A. and Cooper, W.W. (1984), „Some Models for Estimating Technical and Scale Inefficiencies in Data Envelopment Analysis“, Management Science, 30(9), pp.1078-1092.

Banks Bulletin, Year 17, No. 30. (2017). Croatian National Bank. Available at: https://www.hnb.hr/documents/20182/2020824/ebilten-o-bankama-30.pdf/de2b236a-5afa-42fd-a578a84b4adce288

Banks Bulletin, Year 19, No. 32. (2019). Croatian National Bank. Available at: https://www.hnb.hr/documents/20182/2868711/ebilten-o-bankama-32.pdf/3a0e4fc0-e413-49da-2a9b3c9fc0ff0b84

Charnes, A., Cooper, W. and Rhodes, E. (1978), „Measuring the Efficiency of Decision-Making Units“, European Journal of Operational Research, 2(4), pp. 429-444. doi: https://dx.doi.org/10.1016/03772217(78)90138-8 
Cooper, W., Seiford, L. and Tone, K. (2007), Data Envelopment Analysis: A Comprehensive Text with Models, Applications, References and DEA-Solver Software, 10.1007/978-0-387-45283-8.

Cvetkoska, V. (2010), "A two-stage approach for measuring the efficiency applying the methods DEA and AHP", unpublished manuscript, Master thesis. The University of Belgrade.

Cvetkoska, V. and Barišić, P. (2017), „The efficiency of the tourism industry in the Balkans“ in Proc. of the Faculty of Economics in East Sarajevo, Vol. 14, pp.31-41. doi:10.7251/ZREFIS1714031C.

Cvetkoska, V. and Fotova Čiković, K. (2020), "Assessing the relative efficiency of commercial banks in the Republic of North Macedonia: DEA window analysis", Croatian operational research review, 11 (2), 217-227 doi:10.17535/crorr.2020.0017.

Cvetkoska, V. and Savic, G. (2021), „DEA in banking: analysis and visualization of bibliometric data“, Accepted for publication in Data Envelopment Analysis Journal.

Davidovic, M., Uzelac, O. and Zelenovic, V. (2019), „Efficiency dynamics of the Croatian banking industry: DEA investigation", Economic Research-Ekonomska Istraživanja, 32(1), pp.33-49, DOI: 10.1080/1331677X.2018.1545596

Emrouznejad, A. and Yang, G. (2018), "A survey and analysis of the first 40 years of scholarly literature in DEA: 1978-2016", Socio-Economic Planning Sciences, 61, pp.4-8, ISSN 0038-0121, https://doi.org/10.1016/j.seps.2017.01.008.

Farrell, M. (1957), "The measurement of productive efficiency", Journal of the Royal Statistical Society, Series A (General), 120(3), 253-290. https://doi.org/10.2307/2343100

Financial stability report for the Republic of North Macedonia in 2018. (July 2019). National Bank of the Republic of North Macedonia. Available at: https://www.nbrm.mk/content/Regulativa/\%D0\%A4\%D0\%A1\%D0\%A0_2018.pdf

Financial stability report for the Republic of North Macedonia in 2019. (July 2020). National Bank of the Republic of North Macedonia. Available https://www.nbrm.mk/content/\%D0\%A4\%D0\%A1\%D0\%A0_2019.pdf

Fotova Ciković, K., and Cvetkoska, V. (2017), „Efficiency of the Macedonian banking sector: A nonparametric approach”, CEA Journal of Economics, 12(2), pp.17-26. http://journal.cea.org. mk/index.php/ceajournal/article/view/115

Gulin, D., Perčević, H. and Hladika, M. (2012), "The Interdependence Between Bank Provisions and Bank Placements in the Croatian Banking Sector", Theoretical and applied economics, 19, 133-150.

Jemrić, I. and Vujčić, B. (2002), "Efficiency of Banks in Croatia: A DEA Approach", Comparative Economic Studies, 44 (2-3), pp.169-193, 10.1057/ces.2002.13.

Jurčević, B. and Mihelja Žaja, M. (2013), "Banks and insurance companies efficiency indicators in the period of financial crisis: the case of the Republic of Croatia", Ekonomska istraživanja- Economic research, 26 (1), pp.203-224.

Kordić, L. and Visković, J. (2018), "Investigating efficiency of Croatian banking sector - further steps towards more efficient banks", In Mašek Tonković, A. and Crnković, B. (ur.) 7th International Scientific Symposium Gospodarstvo istočne Hrvatske - vizija i razvoj- Economy of Eastern Croatia - vision and growth.

Leightner, J.E. and Lovell, C.A.K. (1998), "The impact of financial liberalization on the performance of Thai banks", Journal of Economics and Business 50, 115-131.

Micajkova, V., and Poposka, K., (2013), "Efficiency of Macedonian Banks: A DEA Approach", Research Journal of Finance and Accounting, Vol. 4, No. 12: 141-149.

Naumovska, E. and Cvetkoska, V. (2016), "Efficiency of the Macedonian banking sector", Yugoslav Journal of Operations Research, [S.I.], v. 26, n. 3, pp. 317-329.

Neralić, L. and Gardijan Kedžo, M. (2019), "A Survey and Analysis of Scholarly Literature in DEA Published by Croatian Researchers: 1978 - 2018", Zagreb International Review of Economics \& Business, 22(1), pp.93-106. https://doi.org/10.2478/zireb-2019-0014

Pavković, A., Cesarec, A. and Stojanović, A. (2018), "Profitability and efficiency of the Croatian banking sector: impact of bank size", Int. J. Trade and Global Markets, 11(4), pp.243-258.

Toçi, V. Z. (2009), "Efficiency of Banks in South-East Europe: with Special Reference to Kosovo", Central Bank of the Republic of Kosovo, Working paper No. 4, pp.1-36.

Tomičić, I., Ćorić, A. and Klačmer Čalopa, M. (2012), "Croatian banking sector research: relationship between ownership structure, concentration, owners' type and bank performance", Journal of Information and Organizational Sciences, 36(2), pp. 159-167. Available at: //jios.foi.hr/index.php/jios/article/view/789 
Tuškan, B. and Stojanović, A. (2016), "Measurement of cost efficiency in the European banking industry", Croatian Operational https://doi.org/10.17535/crorr.2016.0004

Research

Review,

$7(1)$

pp.47-66. 